\title{
PERANAN KEMAMPUAN MANAJERIAL KEPALA MADRASAH DALAM MENINGKATKAN KINERJA GURU
}

\author{
Nurhidayah Muchtar ${ }^{1}$ \\ ${ }^{* 1}$ Pendidikan Agama Islam Fakultas Agama Islam| Unismuh Makassar
}

\begin{abstract}
ABSTRAK
Tujuan penelitian ini untuk mengetahui kemampuan manajerial Kepala Madrasah dan kinerja guru di Madrasah Aliyah Muhammadiyah Datarang. Penelitian ini merupakan penelitian kualitatif, dan informannya adalah kepala madrasah, komite madrasah, guru, dan peserta didik. Teknik pengumpulan data dilakukan dengan observasi, dokumentasi, dan wawancara berupa in-depth interview dan Focus Group Discusion. Teknik analisis data dilakukan dengan mengorganisasikan data, menjabarkan ke dalam bentuk unit-unit, menyusun ke dalam pola, memilih data yang penting dan membuat kesimpulan. Pengecekan keabsahan temuan dilakukan dengan reduksi data, sajian data/ display data dan penarikan kesimpulan. Hasil penelitian menunjukkan Kepala Madrasah Aliyah Muhammadiyah Datarang memiliki kemampuan manajerial yang cukup baik. Kinerja guru di madrasah Aliyah Muhammadiyah Datarang cukup bagus dan dapat dilihat dari 4 aspek yaitu Pertama kinerja yang berkaitan dengan kompetensi pedagogik. Kedua, kinerja guru yang berkaitan dengan kompetensi professional. Ketiga, kinerja guru yang berkaitan dengan kompetensi kepribadian Keempat, kinerja guru yang berkaitan dengan kompetensi sosial.
\end{abstract}

\section{Kata Kunci: Kemampuan Manajerial dan Kinerja Guru}

\begin{abstract}
The purpose of this research was to determine the principals' Managerial Capabilities and teacher performance in Madrasah Aliyah Datarang.This research was qualitative research, and the informant of this research are the principal, school committee, teachers, and students. The data collection techniques was collected through observation, documentation, and interviews in in-depth interviews form and Focus Group Discussion. The data analysis techniques was done by data organize, described in the units form, arranged into a pattern, selected the important data and made conclusions. Checking the validity of the findings by reduction of the data, the data display and decided the conclusions. The result of the reseacrh showed that the head of Madrasah Aliyah Muhammadiyah Datarang has a good managerial ability. The teachers' performance in the Madrasah Aliyah Muhammadiyah Datarang was good and it can be viewed from four aspects: First the performance that related to the pedagogical competence. Second, the teachers' performance that related to professional competence. Third, the teachers' performance that related to personal competence. Fourth, the teacher performance that related to social competence.
\end{abstract}

Keywords: Managerial Capabilities and Teachers' Performance 


\section{PENDAHULUAN}

Kepala Madrasah sebagai pemimpin profesional di lembaga pendidikan mempunyai peran yang sangat penting, mengingat posisinya yang secara struktural sebagai pimpinan legal formal memiliki kekuasaan penuh pada lembaga yang dipimpinnya. Perangkat Sekolah seperti Kepala Madrasah, dewan guru, siswa, pegawai/ karyawan harus saling mendukung untuk dapat bekerja sama mencapai tujuan yang telah ditetapkan. Oleh karena itu dapat dikatakan bahwa sukses atau tidaknya suatu organisasi mencapai tujuan yang telah ditentukan sangat bergantung pada kemampuan pimpinannya untuk menumbuhkan iklim kerjasama agar dengan mudah dapat menggerakkan sumber daya manusia yang ada, sehingga pendayagunaannya dapat berjalan secara efektif dan efisien.

Lembaga pendidikan, baik Sekolah atau Madrasah dibutuhkan Kepala Madrasah profesional, dan juga perlu adanya tenaga kependidikan yang kompeten dan profesional. Hal ini dikarenakan pencapaian tujuan pendidikan sangat tergantung pada kualitas tenaga pendidik, dalam hal ini guru, karena memegang peran sentral dalam proses pembelajaran, yang harus berinteraksi langsung dengan para peserta didik di sekolah/ madrasah.

Madrasah sebagai sebuah organisasi, harus mampu membangun kredibilitas dan kinerjanya secara baik sesuai harapan dari stakeholdernya yaitu tidak hanya menjadi lembaga kepercayaan masyarakat (trustworthy institution) tetapi juga sebagai agen dari pembangunan (agent of development).

Kredibilitas dan kinerja yang baik tersebut ditentukan oleh beberapa pihak baik kinerja pendidik maupun tenaga kependidikan dalam melaksanakan tugas-tugasnya. Hal ini didukung pendapat Prawirosentoso bahwa "kinerja merupakan hasil kerja yang dapat dicapai oleh seseorang atau sekelompok orang dalam suatu organisasi, sesuai dengan wewenang dan tanggung jawab masing-masing". Hal yang sama dikatakan oleh Mangkunegara yang mendefinisikan "kinerja adalah hasil kerja secara kualitas dan kuantitas yang dicapai seorang karyawan dalam melaksanakan tugasnya sesuai dengan tanggung jawab yang diberikan kepadanya".

Paparan di atas mengimplikasikan bahwa guru memegang peran yang sangat penting dan menentukan dalam pelaksanaan pembelajaran di Madrasah. Untuk itu kinerja guru harus terus ditingkatkan agar dapat melaksanakan tugas dan fungsinya mengemban amanat pendidikan seperti yang telah digariskan dalam Undang-Undang Sistem Pendidikan Nasional. Berbagai upaya dan strategi harus dilakukan dengan baik dan terencana agar kinerja guru terus meningkat untuk dapat mencapai tujuan pendidikan yang telah direncanakan. 
Salah satu faktor yang mempengaruhi kinerja guru adalah Kepala Madrasah. Kepala Madrasah merupakan pimpinan tertinggi dalam lembaga pendidikan Madrasah. Perilaku kepemimpinannya sangat berpengaruh bahkan sangat menentukan kinerja guru. Oleh karena itu dalam pendidikan modern, kemampuan manajerial Kepala Madrasah perlu mendapatkan perhatian yang serius. Hal ini penting untuk diperhatikan agar Kepala Madrasah dapat berperan dengan baik dalam mencapai tujuan Madrasah yang telah direncanakan.

Keberhasilan Madrasah banyak ditentukan oleh peran guru dan Kepala Madrasah, meskipun keberhasilan kinerja guru juga sangat ditentukan oleh banyak faktor. Penelitian Gemnafle menyimpulkan bahwa "keterampilan manajerial memberikan kontribusi 33,79 terhadap kinerja guru. Lebih lanjut Gemnafle menyimpulkan bahwa terdapat jalur hubungan kausal langsung yang cukup signifikan antara kemampuan manajerial Kepala Madrasah dengan kinerja guru dalam mengajar pada SMU Negeri dan swasta". Adapun rumusan masalah dalam penelitian ini ialah :

1) Bagaimana kemampuan manajerial Kepala Madrasah di Madrasah Aliyah Muhammadiyah Datarang, Kecamatan Tombolopao Kabupaten Gowa?

2) Bagaimana kinerja guru di Madrasah Aliyah Muhammadiyah
Datarang, Kecamatan Tombolopao Kabupaten Gowa?

3) Bagaimana peranan kemampuan manajerial Kepala Madrasah dalam meningkatkan kinerja guru di Madrasah Aliyah Muhammadiyah Datarang?

\section{METODE PENELITIAN}

Pendekatan penelitian adalah seperangkat asumsi yang saling berkorelasi satu dengan yang lain mengenai fenomena alam semesta dan pada dasarnya ada tiga pendekatan penelitian yang selam ini digunakan dalam penelitian ilmiah yaitu penelitian kualitatif, penelitian kuantitatif, dan penelitian trianggulasi yang merupakan penggabungan dari penelitian kualitatif dan kuantitatif.

Terkait dengan hal tersebut, maka penelitian ini adalah penelitian kualitatif dengan menggunakan dua pendekatan yaitu pendekatan ilmu pendidikan dan pendekatan manajerial. Sumber data dalam penelitian adalah subjek dimana data atau informasi diperoleh. Adapun sumber data dalam penelitian ini ada dua yaitu data primer dan data sekunder.

Penelitian ini merupakan penelitian deskriftif kualitatif yang akan meneliti tentang peranan kemampuan manajerial Kepala Madrasah dalam meningkatkan kinerja guru. Peneliti menganggap bahwa melalui analisis kualitatif peranan Kepala Madrasah sebagai seorang manajer dalam meningkatkan kinerja guru dapat 
digambarkan oleh peneliti dengan menyajikan data dalam bentuk katakata yang dapat dipahami oleh orang lain.

Untuk memperoleh data yang sesuai dengan permasalahan penelitian ini, maka terdapat beberapa teknik atau metode yang digunakan oleh peneliti sebagai berikut:

1. Metode Library Research yakni suatu metode pengumpulan data yang dilakukan dengan mengutip pendapat para ahli yang ditulis dalam buku-buku atau literatur lainnya serta membaca karya tulis ilmiah yang berkaitan dengan judul penelitian.

2. Metode Field Research, yakni suatu metode yang dilakukan dengan turun secara langsung di lapangan dalam hal ini Madrasah Aliyah Muhammadiyah Datarang Kecamatan Tombolopao Kabupaten Gowa guna mengumpulkan data- data atau informasi yang berkaitan dengan kemampuan manajerial Kepala Madrasah dan kinerja guru di Madrasah Aliyah Muhammadiyah Datarang.

\section{HASIL PENELITIAN DAN PEMBAHASAN}

\section{A. Peranan Kemampuan Manajerial Kepala Madrasah Aliyah Muhammadiyah}

Kepala Madrasah berfungsi sebagai manajer/ pemimpin dalam lembaga pendidikan dipimpinnya. Berarti peningkatan mutu akan berjalan dengan baik apabila guru bersifat terbuka, kreatif dan memiliki semangat kerja yang tinggi. Suasana yang demikian ditentukan oleh bentuk dan sifat kepemimpinan yang dilakukan Kepala Madrasah. Menurut Mulyasa, (2004:37) Kepala Madrasah mempunyai 7 peran utama yang yang harus dilakukan dalam meningkatkan kinerja guru yaitu sebagai Edukator, Manajer, Administrator, Supervisor, Leader, Inovator dan Motivator (EMASLIM).

Peran dapat diartikan sebagai perilaku yang diatur dan diharapkan dari seseorang dalam posisi tertentu. Kepala Madrasah sebagai seorang manajer harus mampu untuk menjalankan peran dan fungsinya sehingga tujuan madrasah dapat terealisasi dengan baik. Berikut peneliti menguraikan hasil peneitian tentang kemampuan manajerial Kepala Madrasah dalam meningkatkan kinerja guru di Madrasah Aliyah Datarang.

\section{Peranan Kepala Madrasah sebagai Educator}

Berdasarkan hasil wawancara dengan Kepala Madrasah dalam melaksanakan perannya sebagai educator untuk meningkatkan kinerja guru di madrasah Aliyah Muhammadiyah Datarang dilakukan dengan berusaha untuk meningkatkan pengetahuan guru tentang materi pembelajaran, strategi pembelajaran, teknologi pembelajaran, memotivasi guru untuk disiplin, membina guru 
untuk disiplin, dan berusaha untuk membina perilaku guru.

Jadi dapat disimpulkan bahwa di Madrasah Aliyah Muhammadiyah Datarang Kepala Madrasah Aliyah Muhammadiyah Datarang memiliki kemampuan dalam menjalankan perannya sebagai educator. Kepala Madrasah sebagai pendidik yang diberi tugas tambahan sebagai seorang pemimpin di madrasah senantiasa memberikan arahan dan bimbingan untuk peningkatan kinerja guru dalam mengelola pembelajaran.

\section{Peranan Kepala Madrasah sebagai manajer}

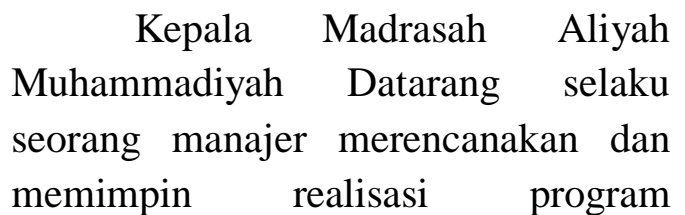
pendidikan madrasah, merencanakan dan memimpin realisasi program fasilitas madrasah, sarana dan prasarana pendidikan di madrasah dan pengembangan guru di madrasah.

Kemampuan M.Jafar B., sebagai seorang manajer di Madrasah Aliyah Muhammadiyah Datarang menurut para guru sangat bagus. Berdasarkan wawancara dengan beberapa orang guru peneliti simpulkan bahwa sebagai seorang manajer memiliki kemampuan yang sangat baik, dalam menyusun program madrasah beliau mempertimbangkan dengan matang sebelum memutuskan dan program yang direncanakan betul- betul direalisasikan bukan hanya sekedar konsep.

Kepala Madrasah Aliyah Muhammadiyah Datarang memiliki program kerja tahunan, bulanan bahkan program harian dan itu semua terlaksana dengan baik. Hal ini disebabkan pengorganisasian, pelaksanaan dan controlingnya sangat bagus. Pembagian kerja yang berimbang dilakukan dengan menyusun kepanitiaan dalam setiap kegiatan-kegiatan madrasah dan penyusunan struktur oganisasi madrasah yang difungsikan. Berikut struktur organisasi Madrasah Aliyah Muhammadiyah Datarang untuk tahun ajaran 2015/2016:

\section{Peranan Kepala Madrasah sebagai administrator}

Pengelolaan administrasi pendidikan di madrasah sangat dibutuhkan sebagai penunjang peningkatan mutu pendidikan. Kepala Madrasah sebagai administrator di madrasah memiliki hubungan erat dengan berbagai aktivitas pengelolaan administrasi yang bersifat pencatatan, penyusunan, pendokumentasian seluruh program madrasah dan bertanggung jawab dalam mengelola program tersebut mulai dari administrasi pembelajaran dan administrasi persuratan oleh karena itu Kepala Madrasah harus selalu memahami, menguasai dan mampu membimbing serta mengarahkan para 
guru dan staf untuk melaksanakan tugasnya sebagai tenaga kependidikan.

Kepala Madrasah $\begin{array}{r}\text { Aliyah } \\ \text { Datarang }\end{array}$
Muhammadiyah
menjalankan perannya dengan baik
dengan melengkapi administrasi yang
dibutuhkan oleh Madrasah dan
memberikan tanggung jawab kepada
masing-masing pelaksana tugas di
bidang administrasi dan setiap bulan
dikontrol Kepala
Madrasah.pencatatan, ran
pendokumentasian program madrasah
dalam pengamatan peneliti tertata
dengan baik.

\section{Peranan Kepala Madrasah sebagai supervisor}

Kepala $\begin{aligned} & \text { Madrasah } \\ & \text { Aliyah } \\ & \text { Muhammadiyah Datarang } \\ & \text { sebagai }\end{aligned}$
seorang supervisor melakukan
supervisi klinis dengan guru dengna
memadukan 3 metode yaitu metode
diskusi, kunjungan kelas maupun
pembicaraan individual. Kepala
Madrasah Aliyah Muhammadiyah
Datarang rutin melakukan supervisi
terkait dengan program perencanaan
pembelajaran dan proses pembelajaran
di kelas.

Dari pengamatan peneliti dilapangan bahwa guru di madrasah Aliyah Muhammadiyah Datarang memiliki perangkat pembelajaran, karena setiap semester mereka memang diharuskan untuk membuat perangkat pembelajaran dan diperiksa secara langsung oleh Kepala Madrasah
Aliyah Muhammadiyah Datarang. Apabila seorang Kepala Madrasah rajin dalam melakukan supervisi maka tentunya dapat meningkatkan kinerja guru, karena tidak ada lagi guru yang berleha-leha tidak membuat perangkat pembelajaran karena selalu dikontrol atau diawasi oleh Kepala Madrasah.

\section{Peranan Kepala Madrasah sebagai leader}

Seorang pemimpin Kepala Madrasah berfungsi menggerakkan semua potensi madrasah khususnya tenaga kependidikan bagi pencapaian tujuan madrasah. Kepala Madrasah harus berusaha untuk menjadi sosok yang ideal, berjiwa besar, dan dapat dipercaya, menghindarkan diri dari sikap dan perbuatan yang memaksa atau bertindak keras sehingga mampu dijadikan panutan oleh para guru, staf dan peserta didik.

Keberhasilan yang dicapai oleh sebuah lembaga pendidikan tentunya tidak lepas dari keberhasilan leadernya dalam memimpin. Begitupun di Madrasah Aliyah Muhammadiyah Datarang. Berdasarkan diskusi dengan beberapa orang peserta didik di madrasah mereka mengatakan bahwa kepribadian Kepala Madrasah sangat patut diteladani terutama kedisiplinan dan ketegasannya. Jujur, disiplin, bersifat terbuka, berwibawa, ramah, berwawasan luas, memiliki visi ke depan melekat kuat dalam pribadi Kepala Madrasah Aliyah Muhammadiyah Datarang. 


\section{Peranan Kepala Madrasah sebagai inovator}

Dalam melaksanakan perannya sebagai seorang inovator Kepala Madrasah harus memiliki kemampuan mencari atau menemukan gagasan baru untuk pembaharuan madrasah.

Inovasi yang dilakukan oleh Kepala Madrasah memperlihatkan beberapa peningkatan di madrasah Aliyah Muhammadiyah Datarang yaitu peningkatan sarana dan prasarana yang menunjang pembelajaran, proses pembelajaran yang lebih baik, kegiatan ekstrakurikuler yang rutin dilaksanakan dan banyak membawa prestasi untuk madrasah Aliyah Muhammadiyah Datarang.

\section{Peranan Kepala Madrasah sebagai motivator}

Motivasi adalah energi aktif yang menyebabkan terjadinya suatu perubahan pada diri seseorang yang tampak pada gelaja kejiwaan, perasaan, dan juga emosi sehingga mendorong individu untuk bertindak atau melakukan sesuatu dikarenakan adanya tujuan, kebutuhan atau keinginan yang harus terpuaskan. Motivasi berfungsi untuk mendorong seseorang untuk berbuat, menentukan arah perbuatan kea rah tujuan yang hendak dicapai dan menyeleksi perbuatan yaitu menentukan perbuatan- perbuatan apa yang harus dikerjakan.

Kepala Madrasah harus mampu membangkitkan motivasi tenaga kependidikan dalam melaksanakan tugas secara optimal, menciptakan hubungan kerja yang harmonis, aman dan menyenangkan, termasuk mampu memotivasi guru untuk menerapkan perilaku disiplin. Motivasi yang dimiliki Kepala Madrasah merupakan kekuatan yang dapat menjadi pendorong bagi bawahannya untuk mendayagunakan potensi-potensi yang ada pada dirinya dan potensi yang ada di luar dirinya untuk mewujudkan pengembangan madrasah yang berkualitas.

$$
\text { Berdasarkan wawancara }
$$
dengan Kepala Madrasah Aliyah Muhammadiyah Datarang beliau mengharapkan bahwa dalam menjalankan peran dan fungsinya sebagai educator, manajer, administrator, supervisor, leader, innovator dan motivator dapat menumbuhkan kinerja guru di Madrasah Aliyah Muhammadiyah Datarang yang bermuara pada peningkatan kualitas pendidikan yang lebih baik.

Dapat disimpulkan bahwa Kepala Madrasah Aliyah Muhammadiyah Datarang mampu meningkatkan kinerja guru dengan menjalankan fungsi manajernya untuk menjalankan perannya sebagai seorang educator, administrator, supervisor, leader, inovator dan motivator. Semakin bagus kemampuan manajerial Kepala Madrasah maka akan semakin meningkatkan kinerja guru yang dapat dilihat dari kemampuan guru dalam mengembangkan kompetensi paeda- 
gogik, kompetensi professional, compete-nsi kepribadian dan kompetensi sosial.

\section{KESIMPULAN}

Berdasarkan penelitian yang dilakukan di Madrasah Aliyah Muhammadiyah Datarang beberapa kesimpulan terurai sebagai berikut:

1. Kemampuan manjerial Kepala Madrasah Aliyah Muhammadiyah Datarang cukup baik indikator kemampuannya dapat dilihat dari tingkat kelulusan peserta didik $100 \%$, semua mata pelajaran diajarkan sesuai dengan kualifikasi akademik masing-masing guru, kompetensi guru yang semakin meningkat, kegiatan pembelajaran yang semakin aktif, peserta didik dari tahun ke tahun semakin meningkat, fasilitas sarana dan prasarana semakin bertambah dan prestasi madrasah semakin meningkat baik di tingkat kecamatan, kabupaten maupun propinsi.

2. Kinerja guru di madrasah Aliyah Muhammadiyah Datarang sudah cukup bagus karena guru sudah memiliki kompetensi pedagogic, kompetensi profesional, kompetensi kepribadian dan kompetensi sosial.

3. Peranan kemampuan manajerial Kepala Madrasah Aliyah Muhammadiyah Datarang terlihat pada kemampuannya menjalankan perannya sebagai seorang educator, administrator, supervisor, leader, inovator dan motivator.

\section{DAFTAR PUSTAKA}

Agus Setiawan, Bahar dan Abdul Muhith. 2013. Transformational Leadership; Ilustrasi di Bidang Organisasi Pendidikan. PT. Raja Grapindo: Jakarta

Arikunto, Suharsimi. 1998. Prosedur Penelitian, PT. RinekaCipta; Yogyakarta

Arikunto Suharsimi dan Lia Yuliana. 2008.

Manajemen

Pendidikan.Aditya Media.

Yogyakarta.

Bafadal Ibrahim. 2008. Peningkatan Profesionalisme Guru Madrasah dalam Kerangka Manajemen Peningkatan Mutu Berbasis Madrasah. Bumi Aksara: Jakarta.

Burhanuddin. 1990. Analisis Administrasi Manajemen dan Kepemimpinan Pendidikan. PT. Bumi Aksara; Jakarta

Danim Sudarwan. 2008. Visi Baru Manajemen Madrasah. Bumi Aksara: Jakarta

Daulay Putra dkk. 2014. Pendidikan Islam dalam Lintasan Sejarah Kajian dari Zaman Pertumbuhan sampai Kebangkitan. PT. Kencana Prenada Media Group; Jakarta

Departemen Pendidikan Nasional. Kamus Besar Bahasa Indonesia. 2001. Cet I, Balai Pustaka; Jakarta 
Departemen Pendidikan.Undang-

Undang Sistem Pendidikan

Nasional. 2011. Cet. IV; Pustaka

Pelajar; Yogyakarta

Dharma Agus. 2001. Manajemen

Supervisi; Petunjuk Praktis bagi

Seorang Supervisor. PT. Raja

Grafindo: Jakarta

Fadjar Malik. 1998. Visi Pembaruan

Pendidikan Islam, LP3NI;

Jakarta

Fatah N. 1996. Landasan Manajemen

Pendidikan. PT. Remaja

Rosdakarya: Jakarta

Getteng, Rahman. 2012. Мепији Guru

Profesional dan Beretika.

Alauddin Press: MakassaR.

Gunawan. 1996. Administrasi Sekolah.

PT. Rineka Cipta: Jakarta

Handoko T. Hani. 1995. Manajemen.

BPFE; Yogyakarta

Hasibuan H. Malayu. 2005.

Manajemen Sumber Daya

Manusia. PT. Bumi Aksara;

Jakarta

Henry Simamora. 2000. Manajemen

Sumber Daya Manusia. Bagian

Penerbitan STIE YKPN;

Yogyakarta

Ilyas Y. 1999. Kinerja Guru. FKM UI;

Depok 